\title{
Case Study: \\ Desert Storm And The Entrepreneurial Spirit
}

Falih M. Alsaaty, (Email: FAlsaaty@cox,net), Bowie State University

\begin{abstract}
This case is appropriate for any college level entrepreneurial class. The purpose of this case study is to explore the business experience of an Iraqi entrepreneur, and share it with the community of entrepreneurs worldwide. The paper traces the journey of Mr. Sammy Awad, the entrepreneur, from the 1991 Gulf war to the fall of Baghdad to Coalition Forces in 2003. The Gulf war caused widespread devastation to the Iraqi economy, and large scale unemployment. On the other hand, the war created lucrative market opportunities for entrepreneurs, including Mr. Awad who, in a few years time was capable of moving from being a conscript in the Iraqi armed forces with a trivial salary, to a taxicab driver, and finally to an owner of a fleet of taxicabs. His stamina, determination, and foresight make him a role model for young entrepreneurs around the world.
\end{abstract}

\section{INTRODUCTION}

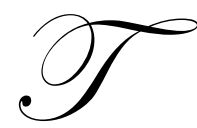

he Gulf war, dubbed Desert Storm, is attributed to the movement of the Iraqi army towards southern territories, and the eventual capture of Kuwait, an oil-rich emirate the size of Hawaii with a population of 2.1 million, of which only 36 percent are citizens. The war, which broke out on January 16, 1991 and lasted 42 days, brought about devastation to the Iraqi economy as well as hardship to its people. The nation witnessed decapitation of the country's infrastructure, imposition of economic sanctions, skyrocketing prices, and soaring unemployment rates. At the end of the war, hundreds of thousands of individuals, who worked for the state in various capacities, found themselves suddenly without jobs or sources of income. The war exhausted the state's financial resources. Under socialist policies, the nation's key sectors, including trade, finance, insurance, petroleum, and pharmaceuticals were all controlled by the state, making the government the chief employer. The private sector, which consisted mainly of small business firms, was weak and insignificant.

The Gulf war proved to be prohibitive. A large segment of the Iraqi armed forces was demobilized, and the decision to scale back employment was extended to include most governmental departments and units. Indeed, decisions to downsize the public sector were relentless. The practice of forced retirement and outright dismissal of employees was widespread. It was clear that the dominance of the public sector, as the engine of growth, was crumbling. Despite destruction and despair, the war opened new windows of opportunity for local entrepreneurs and small business owners. To alleviate the impact of massive unemployment, the restrictions on the private sector were steadily relaxed. A new era for Iraqi entrepreneurs appeared to emerge.

\section{THE COUNTRY}

Mesopotamia is widely recognized as the cradle of civilization. It symbolizes the contributions of the peoples of Iraq to science, technology, law, and medicine throughout the history of mankind. Writing, the wheel, and the mathematical system, for example, were all invented in the land between the two rivers - the Tigris and Euphrates. World economic progress would have been difficult without the ingenuity of the Sumerians, Assyrians, Akkadians, Babylonians, and Abbasids. Mesopotamia is the Greek term for the state of Iraq, a county rich in culture, as well as resource endowment. In terms of petroleum, for example, Iraq possesses the second largest oil reserve in the world ( $11 \%$ of the global reserves) after Saudi Arabia. In addition, a sizable segment of the Iraqi population is highly educated, skilled, and productive. The modern state of Iraq, with a population of 25 million, was created in 1921, and gained its independence in 1932, after centuries of foreign occupation. In recent years, Iraqis experienced little stabili- 
ty and prosperity. Wars and domestic conflicts had engulfed the country for more than three decades, consuming invaluable resources. In addition, the nation had been under punishing economic sanctions for nearly thirteen years ending in April 2003.

From economic standpoint, the petroleum sector, as one might expect, had been the dominant industry, generating about 90 percent of the country's foreign exchange receipts. Other key industries included textiles, cement, electrical goods, leather products, plastics, pharmaceuticals, and sugar refineries. Many of the companies comprising the local industries were state-owned, and small in size relative to their counterparts in developed nations.

\section{A TOUR OF DUTY}

Sammy Awad, an 18-year-old high school graduate, was drafted into the army in 1989. His dream was to study economics at Baghdad University, become an influential businessperson, and lead an important organization. But he was denied admission to the university, because of his poor performance in the national high school examination. His overall performance was so dismal that his application was also rejected by a number of community colleges. To be able to enroll in a university or community college, students are required to pass a centralized national test at the end of their high school years. On the basis of the test result and the student preference, he/she is then assigned to a state educational institution. Each institution throughout the country had an annual quota as to the maximum number of students to be admitted. It's important to note that Mr. Awad's dismal performance in the test didn't at any rate reflect his potential or academic knowledge. He simply didn't have enough time to prepare for the test, because of his father sudden death during the examination period. He was indeed a clever young person, full of energy and ambition, aspiring for success.

Young men had been subjected to compulsory military service during much of Iraq modern history, until this law was abolished after the fall of Baghdad in April 2003. Mr. Awad was assigned during his tour of duty to a transportation unit responsible for delivering food supplies to the troops. After a few training lessons, he found himself alone in the driver's seat of a six-wheeler delivering provisions. The working hours were very long and tedious, while the salary he received was equivalent to $\$ 1.50$ a month. Despite the risks encountered, especially during the Gulf war, he felt that he was fortunate for not being directly involved in combat. He had mixed feelings about the war, its causes and consequences. He wanted to serve his country, but not in the capacity of a soldier. A couple of months after the end of the Gulf war, however, Mr. Awad was discharged from the army, without fanfare or compensation. He thought that he was blessed for being alive and unscathed.

\section{THE SEARCH FOR A JOB}

The war now was over, and he was a free man again. The nagging problem was finding employment. Jobs were scarce and income was hard to come by. He thought that survival was becoming more difficult, because he lacked career skills and a college degree. His work experience was confined to driving; the army offered him little else in terms of training or formal education. Employment options were, therefore, extremely narrow. He figured out that the most logical alternative for him was a job as a taxi driver, an occupation with relatively good earnings prospects, and perhaps the least difficult to attain. Taxis in Iraq, like in many developing countries, are mainly owned and operated by individuals, with the absence of companies owning a large fleet of automobiles. The lack of major players in the market was an attractive opportunity for entrepreneurs to take advantage of. However, Mr. Awad soon discovered that the job he was looking for was difficult to find, because getting employed in Iraq, required personal connections, or professional skills. In seeking an extra hand, small business owners resort to hiring individuals from among family members, relatives, or close friends. Business owners don't employ any individual who happens to come their way. They require recommendations for the job seeker to ensure his/her loyalty and proper behavior. Generally speaking, qualifications occupy a secondary importance in making employment decisions. Of course, Mr. Awad was in the hunt for employment in the private sector, due to the fact that government agencies weren't in a position to offer employment under the circumstances.

Obedience and discipline were the most prominent characteristics that Mr. Awad acquired during his service in the army. But he also had other desirable traits. Like most Iraqis, he treasured family and friends. He was generous, 
sincere, trust worthy, and caring. He was also industrious, though somehow emotional and aggressive. The task of finding employment, nonetheless, was definitely daunting. He must first identify a taxicab owner who was in need of a driver, or someone else prepared to hire him for this purpose. He was willing to work part-time, or even on a temporary basis. He urgently needed a steady source of income. Second, he must convince a potential employer that he was reliable, honest, and loyal. He certainly couldn't purchase an automobile of his own. For one thing, the importation of automobiles into Iraq was restricted, because of the economic embargo imposed by the international community. Therefore, prices of existing automobiles, even the oldest models, were sky-high. He possessed no personal savings to finance the acquisition of an automobile, nor was his family in a position to help. In fact, his family, like most middle-income families, was barely surviving on a steadily declining income. Many families were selling, particularly during the early 1990's, their own household appliances or other possessions in order to supplement limited earnings. Finally, Mr. Awad didn't have the option of automobile financing, because such a facility wasn't available in Iraq. Cash payment was required, as was the case with most business transactions.

\section{AN EMPLOYMENT OPPORTUNITY}

In August 1991, four months after being discharged from the army, Mr. Awad came across a distant relative who owned a small real estate company. The man was interested in someone to employ who would pick up potential clients and drive them around to view available properties. At the time, real estate, especially land speculation and residential properties, was exceedingly an attractive business. Real estate activities were profitable, less risky, and involved minimum government interference. Within a week, Mr. Awad was happily touring properties accompanied by clients in his employer's automobile - a 1974 Dodge Dart.

The assignment was straightforward. Pick up prospective clients from the office location, take them to the desired site, show them around, and bring them back to the office. All issues related to the asset under consideration, including property description, price, and payment plan were to be discussed with the boss. The man shared his business experience with his new and only employee, but kept much of the work for himself. Mr. Awad felt comfortable with the arrangement, and enjoyed the simplicity of his task. He worked ten hours a day, and made an average of two trips daily, six days a week. On Fridays, the Muslim holiday, business activities are suspended, and socializing comes to the forefront.

Mr. Awad learned a lot about the real estate business during the past few years he had been on the job. For example, he became familiar with regulations, negotiation strategies, as well as selling practices. He also gained insights into the behavior of people and their personalities. As a result of his interactions with clients, he discovered that many of them were truthful, highly emotional, easily swayed, and naive about real estate properties. He also found out that the real estate sector was increasingly becoming inundated with speculation, an activity that pressured prices enormously.

The market domain for his boss' operations was the greater Baghdad metropolitan area, a city of about five million inhabitants. In this market, there were approximately fifty independent business owners/brokers. The commission was flexible, and normally determined by a verbal agreement between the broker and the seller, and was influenced partly by the price of the property under discussion, and partly by the nature of relationships, if any, between the broker and the seller. National standards governing real estate practices were absent. Additionally, the sector was subject to less restrictive regulations, as compared to other areas of the economy such as manufacturing and banking. As pointed out earlier, Mr. Awad had a pleasant personality. He was articulate, and took pleasure in assisting others. $\mathrm{He}$ also promoted a strong social network, because it provided him with the support system he craved for. Cultivating the relationships he methodically fashioned was very much on his mind.

\section{A BRIGHT OUTLOOK}

Mr. Awad felt that his job was fairly interesting, and financially adequate. He didn't complain about his boss, or expressed dissatisfaction with the responsibilities assigned to him. But real estate, as a profession, didn't appeal to him. He wanted a job that offered him more independence, more freedom of action, and more income. He sought to be a taxicab driver. That was the business of his picking, and he deemed nothing more pleasing. In less than four years of 
being employed in real estate, his dream came true by chance. On a hot summer day, Mr. Awad took an old lady on a tour for some properties. The woman was amicable, and interested in conversing. On the way back to the office, she told Mr. Awad that the year before she lost her husband of thirty-five years, that she never had children, and that she had some extra money for investment. She also inquired if he could recommend an alternative investment to a property purchase. Property prices, she said, were excessive.

Without hesitation, he explained to her the advantages of owning a taxicab, particularly the daily revenues that came with it in a growing city such as Baghdad. In a convincing manner, he pointed out that the investment was safe, and it could double in value in a short period of time, because of rising automobile prices. Finally, he offered his services as a partner by suggesting that she might buy the automobile and keep the title in her name, that he would operate the vehicle, and that she would receive, net of all expenses, fifty percent of the daily proceeds. He asked her to keep the discussion confidential from his boss, but if she so desired, could investigate his reputation and character from neighbors and friends.

Many well-to-do families are accustomed to having a large portion of their wealth in the form of cash and/or jewelry stored at home. Other families prefer to store their wealth in the form of real estate holdings. Still a few others have chosen to transfer a great deal of their wealth to European countries, especially the United Kingdom because of the country's historic relationship with Iraq. The nation's financial infrastructure had remained backward, and incapable of attracting large funds from the society. The use of personal checks and credit cards, for instance, was extremely limited. The old lady, illiterate and lonely, had the bulk of her assets, though not very large, in the form of cash "under the mattress", readily available to be put into productive investment.

On a Friday evening, a few days after their first meeting, the old lady came to his home seeking further clarification about the proposal. She wanted to make sure, once the automobile is bought, that she will be the sole owner, and that he will refrain in the future from claiming a share in it. She also required him to swear under God (Allah) that he would not betray her trust under any circumstance. A written contract wasn't necessary, because she trusted that his word reflected his honor. In fact, honor is an important aspect in the life of Iraqis, and they tend to do whatever it takes to protect it. Mr. Awad was, of course, eager to comply with her request. He was thrilled, because he regarded the arrangement a turning point in his life, a big step forward. Despite the happy news, he couldn't sleep well that night. He kept thinking about the old lady, and how innocent she was for completely trusting a man she barely knew. But then he realized that her case wasn't an aberration. Quite a few people whom he had met over the years fell in this category. Many of them were good-hearted to the point of being gullible. Yet, he was inclined to be honest to the partnership, and to avoid disheartening her.

\section{A TURNING POINT}

On an early morning in July 1995, Mr. Awad was driving a taxicab on a Baghdad street in the direction of the Tigris river, with two passengers sitting in the back of the automobile. That sunny, hot day was his first day on the job. The feeling of being in control was overwhelming. He could go anywhere in the city at will, and render the service to passengers of his own choice. He wasn't required to station in a specific location waiting for customers to arrive, or respond to service calls from a dispatcher. There was also a lack of guidelines for taxicab fares. Fares were influenced by a number of factors, including the distance to be traveled, the year and make of the automobile, and the perceived financial status of the passengers. In general, passengers inquire about the fare in advance, and negotiate the total asked of them. The lack of a taxicab meter or other regulating factors had led some operators to charge exuberant fares from those who were in desperate need for the service.

At the time, Baghdad was peaceful and serene. No bombing raids, or gasoline shortage, or fear of mugging. From Mr. Awad's perspective, things were looking pretty good, and improving. On the other hand, due to a confluence of reasons, the public transportation system was collapsing. Buses, for example, were too crowded, too slow, and too dirty. On some heavily traveled bus routes, it took an average of two hours to travel a ten- mile distance, in addition to an hour waiting period. Baghdad didn't have an underground metro system, perhaps because the city is sitting on a massive well of petroleum. This state of affairs opened a new window of opportunity for the private transportation sector. A boom of taxicab service took place throughout the country. Some middle class citizens, as a result of 
deteriorating standards of living, began to convert personal automobiles into taxicabs, and become themselves the operators. It is to be noted that people, under the pressure of circumstances, will attempt to come up with ingenious methods to help them stay alive, and to feed their families.

Mr. Awad cleverly exploited the rapidly expanding market opportunity, by working fourteen- hour shifts, from six o'clock in the morning to about eight o'clock in the evening, six days a week. As a taxicab driver, his overriding goal was to attain a high standard of conduct. He charged reasonable fees and, whenever possible, took direct routes to the desired destinations. He treated people with respect, and refrained from taking advantage of vulnerable passengers. His integrity and tenacity paid off handsomely. He was able to cultivate a group of regular, and generous, clients. Among them were four female university students who, together, needed round trip daily services. For the majority of operators, the job of driving a taxicab was financially rewarding. His average monthly net income of about $\$ 300$ was roughly equivalent to that of the yearly income he made in his previous real estate job. He was prudent in spending, preferring to save the larger part of earnings.

\section{THE DRIVE FOR SUCCESS}

As the time went by, Mr. Awad had increasingly become preoccupied with critical issues for which he sought answers: Why couldn't he become his own boss? Why did he need a partner? Why should he share his hard earned income with somebody else? His thought process led him to decide to get out of the partnership, and launch his own taxicab service. He had accumulated sufficient funds to enable him to acquire an automobile of his own. He decided that he shouldn't feel awkward in confronting the old lady about dissolving the partnership. He had made her a lot of money within the past years. Her share of the proceeds was more than the original amount she invested in the vehicle. Mr. Awad was determined to meet with the old lady the next day to notify her of his intention. He also decided to inform her about his readiness to purchase her automobile at the going market price, if she so desired.

Throughout the meeting, the woman was emotional and furious. She told him that she thought the partnership was a long-term arrangement, that he was betraying her confidence in him, and that he, as a man, should honor the commitment he made. Mr. Awad was surprised and bewildered. He had come to know her as a coy, reserved, and courteous individual. Now she seemed brazen and sinister. She kept crying and lamenting her misfortune. He offered to find a dependable driver to replace him in a matter of days, and that his decision to quit was final. In addition, he proposed to buy her vehicle at a price that was ten percent higher than that of the market. At last, the old lady relented, however, she remained visibly upset and hostile. But Mr. Awad maintained his calm and composure throughout the encounter. He knew that in Arab culture, people defend essentially three distinct matters: God, honor, and wealth. The old lady, he figured out, was doing the right thing by protecting her financial interests.

It's a good thing if a person is engaged in a business activity of his/her liking. But it's a great thing if the person creates a business of his/her liking. "Feeling great", that was Mr. Awad's state of mind after concluding the transaction for the purchase of the old lady's automobile. His joy was boundless. On a Sunday in March 1997, he felt like he was reborn again, and was in a stage of self-actualization. The event was indeed a landmark in his life. Although Mr. Awad didn't receive a college degree in business, he was intelligent enough to know the value of planning. Now that he was a businessperson, he knew he must plan for the road ahead, and anticipate potential obstacles that might lie in the way. Owning a single taxicab could be the beginning of bigger things to come. Only time would tell.

It wasn't all pleasure and happiness, however. The job of driving a taxicab for long hours in mostly narrow, congested streets was certainly an exacting task. For one thing, many motorists ignored the rules of safe driving, and drove aggressively. There was also a lack of officially designated street crossing areas, and pedestrians were careless. Finally, traffic lights in many locations were either missing or out of order. Hence, accidents occurred frequently, though many of them were relatively minor, and could be settled on the spot, without the need to go to courts or even involve the police. Often, the speed at which motorists can travel is constrained by crowded streets and slow traffic. Unlike taxicab operators who were new to the profession, Mr. Awad was highly skilled and careful. He obeyed traffic regulations more often than not. Only once was he involved in a traffic accident, in which case he bumped into a bicyclist from the rear and caused him to be thrown about five yards away. It looked like the man was slightly hurt. Mr. Awad settled the matter by giving him the equivalent of three dollars. Getting involved into traffic accidents wasn't a 
major concern for many people. External events, good or bad, according to Islamic teaching, as most Iraqi are Muslims, are predetermined, and that believers should thank God for their occurrence, because these externalities portray significant meanings.

\section{THE DESIRE FOR A BIGGER PIE}

The public transportation service went from bad to worse during the three years since Mr. Awad chose to change his career. Meanwhile, the demand for taxicab service exploded. Along with escalating demand came a steady stream of income for those involved. There were a number of factors affecting the transportation sector at the time. Among them were the following: (1) Iraq's population was increasing at a rate of 2.5 percent annually, resulting in ever increasing demand for land transportation, both public and private. It is interesting to observe that the government provided financial incentives to each child was born to a family. The purpose was to increase population size. (2) The influx of a large number of people from different parts of Iraq to the capital city Baghdad in search for employment, and to improve their standards of living.

There were other significant developments that positively influenced the private transportation sector in Iraq. For instance, in the 1990's, the Iraqi government initiated a privatization program to stimulate sagging economic activities. The program, though limited in scale, forced government agencies to dispose of most of their automobile holdings. The disposal plan was aimed at accomplishing two functions: (A) to generate additional revenues for the government, and (B) to trim down public spending. The automobiles were sold in public auctions on different occasions and at compelling prices.

During the first two years as an independent owner/operator, Mr. Awad had accomplished a couple of vital goals. First and foremost, he saved enough money to put toward the purchase of a second vehicle. Second, he gradually expanded the base of regular clients, mainly because of his politeness, punctuality, safe driving, and reliability. Third, he rented a house in a middle-income neighborhood, a quiet area made up of a collection of single- family homes. The neighborhood was so lovely that he wished to own a home in the area, intended as a token of appreciation for his mother for her many years of hardship. Mr. Awad was an ambitious young man, looking forward to establishing a viable taxicab company. As a matter of fact his vision was to own a fleet of vehicles, and to lead a group of operators under his command. He also fantasized about making strategic decisions that affected the future of a large group of employees. He had been planning for this kind of decisive moment in his life. He even prepared a list of dependable individuals as potential employees in his company.

Government sales of automobiles were publicized widely, not by the agencies themselves but by word of mouth. The move was regarded, particularly among the educated public, as an indication of poor economic management, and the blatant failure of socialist policies. Whatever the case may be, the sales attracted a large crowd of prospective buyers, each vying for a piece of the pie. Mr. Awad was among the lucky ones. The vehicle he bought was a 1990 Mercedes Benz, fully equipped, and in good condition. Immediately after the purchase was completed, he was offered a 15 percent price increase, but opted for keeping the vehicle. It was a big catch, he thought. And it will be in use for regular customers, and those who were willing to pay premium fares for distinguishable rides. Unlike the case in some neighboring countries such as Jordan and Lebanon, for instance, one rarely saw a Mercedes Benz as a taxicab on Baghdad streets, because they were very expensive relative to other available automobiles.

Mr. Awad had already made up his mind to hire a trusted friend. He planned to offer him 50 percent of the net weekly income, that is, an income net of the cost of gasoline, repairs, and other incidental spending. The intended scheme was similar to the agreement he had concluded in the past with the old lady. It was an attractive offer under the circumstances. In the beginning, it wasn't easy for him to let someone else take control of his automobiles, not even a close friend, because the arrangement was fraught with risk. At the time, there were no legal requirements for automobile insurance, and insurance premium was costly. Thus, in the event of a theft or a wreck the owner alone would have to bear the cost of replacement, with no monetary compensation expected. The anxiety about someone else driving his automobile dissipated in a couple of days, as Mr. Awad was preoccupied with other pressing issues. 
One ought to admire the perseverance of the Iraqis. Under debilitating sanctions, many of them, especially those who had lost their jobs in the public sector, were able to find ways to make a living. Some individuals earned their livelihood by accepting menial, low-paying jobs in spite of possessing good qualifications. Other individuals became small business owners. They engaged in selling a variety of items such as used books, shoes, clothes, furniture, and spare parts. Still few others opted for more risky entrepreneurial activities such as manufacturing or establishing distribution centers for products. It was widely reported in the press that the country's per capita income declined substantially in the 1990's as compared to its levels in the 1970's, while the number of individuals who became "super rich" increased dramatically. It seemed that the economic sanctions had created lucrative opportunities for those who were in a position ready to exploit them fully. The demand for taxicab services in Baghdad continued to intensify, as was the case for almost all consumer goods and services, for reasons outlined earlier.

The taxicab operator who was hired proved to be trustworthy. He never missed a beat. The man worked diligently, and demonstrated integrity. Despite the absence of a meter in the vehicle to help gauge revenue, the income he generated, taking into consideration the number of hours worked, was approximate to the amount made by Mr. Awad as the previous driver for the automobile. Mr. Awad was convinced that, as the outlook for taxicab service kept improving, it was within reach to double the number of automobiles in his possission within a couple of years. In his judgment, the growth of the taxicab business was essentially governed by five external forces: (1) the future state of the public transportation, (2) the expansion of the private sector, (3) the intensity of competition among various players (i.e., taxicab service, minivan service, bus service, and public transportation), (4) the future of the economic sanctions, and (5) the health of the economy.

By and large, it was difficult to assess with any degree of accuracy the future course of the business, because many interrelated variables were simultaneously at play. But, Mr. Awad's gut feeling was that the overall direction of events was positive, indicative of promising outcomes. The benign assessment of the external environment encouraged him to be more determined in growing his own business. Of course, he needed kind of a road map to guide him towards the achievement of his objectives. His vision was clear, and straightforward: First, he wanted to build a taxicab company from the ground up, a company of his choice and employees of his selection. It was an opportunity not to be missed. Second, he strived for financial security and independence in the long run. Third, he sought to occupy a position of authority.

\section{GOING FORWARD}

In 2000, more than two years since he bought the second automobile, Mr. Awad decided that it was the right time to expand the business by acquiring a third automobile. The necessary ingredients for the move forward were all in place: the money, the employee, the will power, and the insatiable demand for taxicab services in Baghdad. In the interim, the country was on the path of economic recovery, due largely to the absence of wars, and rising petroleum production. The feeling of stability, confidence, and hope was widespread among the population. The normalization of relationships between Iraq and a number of countries in the region served as an impetus for further improvement in the domestic economic environment.

On a Friday in a Baghdad bazaar, Mr. Awad came across the old lady, the women whom he worked for in the past. After a brief chat, she expressed interest in joining forces with him in the taxicab service once again. She was aware of his attainment, and willing to accept a reasonable deal he might come up with. She also told him how confident she was in his talent and integrity, and that she needed him as a business partner. He promised her that she would get a response a few days later. The creation of a partnership, through the infusion of new resource, was initially an appealing idea for Mr. Awad, because the old lady was to contribute capital to the enterprise, and share the risk. On the other hand, he figured out that she wasn't in a position to help strategize or manage the new venture. She lacked the necessary work experience and the knowledge of the industry. In other words, her role in growing the business would be negligible. In addition, Mr. Awad had an unpleasant encounter with her during the last few days of their business relationship. He reflected upon her obnoxious attitude toward him, and her crying and screaming. Therefore, he decided to decline her offer. 
A used car in relatively good working condition was bought and put into service at the end of 2001. During the same time period, Mr. Awad quit driving, and assigned the responsibility of driving his car to a friend employed for this purpose. A business enterprise called "Tigris Taxi" was born, consisting of four individuals and three automobiles. As a result of the overall situation in Iraq, many small business firms ignored licensing requirements in order to avoid paying fees and taxes, and to stay away from bureaucratic procedures. "Tigris Taxi" was among them. As a matter of fact, very few taxicabs roaming the streets bore any identifiable trade name or marking.

The task of supervising the activities of the drivers was effortless. They were hand picked, loyal, and committed. The oral agreement with them stipulated that they were to meet with Mr. Awad twice a week (Fridays and Tuesdays) in the evening in a neighborhood café. The purpose of the meetings was to hand over Mr. Awad's share of the income made in the previous days, and to discuss other business issues. The drivers were required to work a minimum of eight hours a day, but on a flexible schedule (e.g., four hours in the early morning and four hours afternoon). No other provisions or restrictions were discussed or imposed. The drivers were left pretty much on their own in matters such as automobile repairs, location served, and the like. Moreover, each driver was expected to bring in, on average, $\$ 35$ a day, an amount equivalent in local currency to the monthly salary of four high school teachers in 2002.

Things were going smoothly, and the future for Mr. Awad seemed brighter than ever. The business was brisk, the drivers were productive, and the money kept coming. Once in a while, accidents were caused by his associates, or by other motorists, made him annoyed. He became financially secure, and was in firm control of the business enterprise. He had achieved a status in society that no one in his family had ever accomplished. He also broadened his social network, and developed relationships with a number of government officials. Mr. Awad's most potent tool in getting things done was gift- giving. Gift- giving is an important cultural trait of the Iraqi society. Normally, people value gifts and appreciate the gift- givers. Gift- giving was particularly effective in dealing with most government departments for the reason that the employees, faced with hyperinflation and stagnating income, were receptive to offerings of any kind, though the practice was officially illegal. The overwhelming feeling of success wasn't enough to make Mr. Awad content, or deter him from planning further for the future. He wanted to see the business grow bigger and bigger, as he had been powered by a strong desire for wealth and influence. With the kind of revenues flowing in, he estimated that, every eight months, an additional automobile could be bought. He believed that nothing would stand in the way of reaching his goals.

\section{THE LEAP UPWARD}

In late 1990's, the Iraqi government intensified its economic reform efforts, especially the implementation of measures to accelerate privatization programs. Thus, an increasing number of privately owned universities and community colleges were established. Though the cost of matriculation in private institutions was expensive, the availability of relatively easy access to higher education made it possible for thousands of high school graduates, who were previously unable to enroll, to pursue higher education. The accessibility of college education constituted an additional incentive for Mr. Awad to acquire new skills and knowledge. His intention was to familiarize himself with concepts and techniques that might help him manage the company more effectively, rather than to purely pursue a business degree. His areas of interest were management, accounting, and finance. He made substantial progress during the first year as part time student in 2003. In the meantime, he added a fourth automobile to his fleet. He began to apply many of the ideas and techniques he learned to his business operations. For example, he organized the accounting records in such a way as to help him analyze the information gathered for each automobile in terms of revenue, repair cost, and miles traveled. Formal education also provided him with insights into resource management and strategies. Specifically, he learned about planning procedure, control systems, performance evaluation, and effective leadership practices. He realized that, as the business operations get bigger, he must adopt an appropriate organizational structure, delegate authority, keep official records, and provide leadership. Armed with new knowledge, Mr. Awad appeared to be fully prepared for the future.

\section{TEACHING NOTE - Suggested questions}


1. Do you think that Mr. Awad is a true entrepreneur? Explain.

2. In your judgment, what should Mr. Awad's next move be?

3. Should Mr. Awad adopt a diversification strategy for his business? Discuss.

4. What are the potential obstacles that Mr. Awad might face in his efforts to expand the business?

\section{NOTES}


NOTES 